\title{
PENGARUH EKSTRAK KAYU MANIS TERHADAP PENURUNAN KADAR GULA DARAH PADA PENDERITA DM TIPE II DI DESA KUMANTAN WILAYAH KERJA PUSKESMAS BANGKINANG KOTA
}

\author{
Syafriani ${ }^{1}$ Besti verawati ${ }^{2}$ \\ Dosen FIK Universitas Pahlawan Tuanku Tambusai, Riau, Indonesia \\ syafrianifani@ymail.com, besti_verawati07@yahoo.com
}

\begin{abstract}
Abstrak
DM tipe II adalah suatu sindrom yang terjadi karena gangguan metabolisme karbohidrat, protein dan lemak serta terjadinya komplikasi akut dan kronis Di dunia DM tipe II merupakan penyakit degeneratif dengan prevalensi tertinggi yaitu urutan nomor 4 (Tara, 2006). DM tipe II merupakan jenis penyakit DM yang sebagian besar diderita yaitu sekitar 90\% hingga 95\%. Penderita DM tipe II paling banyak diderita oleh orang dewasa yang berusia lebih dari 30 tahun dan cenderung semakin parah secara bertahap (Manganti, 2014).

Jenis penelitian ini menggunakan metode eksperimen semu (quasi exsperimen) dengan rancangan non-equivalentpretest-posttest. Intervensi yang digunakan dalam penelitian ini adalah pemberian ekstrak kayu manis $2 \mathrm{x}$ sehari pada pagi dan sore selama 7 hari. Metode non-equivalent pretest-posttest ini digunakan untuk melihat pengaruh konsumsi ekstrak kayu manis terhadap penurunan kadar gula darah penderita diabetes mellitus. Penelitian ini dilaksanakan pada bulan April-Agustus di Desa Kumantan wilayah kerja puskesmas Bangkinang kota. Analisis data yang digunakan pada penelitian ini adalah analisis deskrifitif meliputi data karakteristik responden dan analisis inferensia meliputi pengaruh ekstrak kayu manis terhadap penurunan kadar gula darah pada responden.

Hasil penelitian menunjukkan bahwa terdapat penurunan kadar gula darah responden setelah intervensi ekstrak kayu manis, yaitu sebesar $37.75 \mathrm{mg} / \mathrm{dl}$, dimana kadar glukosa darah sebelum intervensi sebesar 263,40 $\mathrm{mg} /$ dan setelah intervensi sebesar 225,65 mg/dl. Diharapkan untuk penelitian selanjutkan menggunakan sampel kelompok pembanding dengan periode intervensi lebih lama agar penurunan kadar gula darah mencapai normal dan ditambahkan intervensi lain untuk pengontrolan penurunan kadar gula darah berupa pendidikan gizi, komsumsi pangan, dan aktivitas fisik.
\end{abstract}

Kata Kunci: Ekstrak kayu manis, DM tipe II, kadar glukosa darah

\section{Pendahuluan}

Seiring perkembangan zaman, kementrian kesehatan telah melaksanankan beberapa program untuk menunjukkan berbagai dampak positif dibidang kesehatan. Hal ini dapat dilihat tingginya angka harapan hidup. Adanya perubahan pola hidup sehat membawa konsekuensi terhadap perkembangan penyakit degeneratif, salah satunya adalah diebetes melitus (DM) Tipe II.

DM tipe II adalah suatu sindrom yang terjadi karena gangguan metabolisme karbohidrat, protein dan lemak serta terjadinya komplikasi akut dan kronis. Di dunia DM tipe II merupakan penyakit degeneratif dengan prevalensi tertinggi 
yaitu urutan nomor 4 (Tara, 2006). DM tipe II merupakan jenis penyakit DM yang sebagian besar diderita yaitu sekitar 90\% hingga 95\%. Penderita DM tipe II paling banyak diderita oleh orang dewasa yang berusia lebih dari 30 tahun dan cenderung semakin parah secara bertahap (Manganti, 2014).

Berdasarkan

laporan

International Diabetes Federation tahun 2015, jumlah populasi Indonesia yang terkena diabetes mencapai 9,1 juta orang dan $53 \%$ penderita diabetes di Indonesia tidak menyadari bahwa dirinya terkena diabetes. Sebelumnya pada tahun 2011, Indonesia berada pada peringkat ke-10 untuk kasus diabetes tertinggi di dunia dengan jumlah penderita 7,2 juta jiwa dan naik pada tahun 2013 menjadi peringkat ke7 dengan jumlah penderita sebanyak 8,5 juta jiwa. Tahun 2014, Indonesia berada pada peringkat ke-5 untuk jumlah penderita diabetes tertinggi di dunia.

Di Provinsi Riau khusunya kota Pekanbaru diketahui terdapat 6.018 pasien dengan penyakit DM tipe II pada tahun 2013 data berdasarkan rekam medik RSUD Arifin Ahmad. Data dari Dinas Kesehatan Kabupaten Kampar tercatat jumlah penderita DM tipe II di Kabupaten Kampar tahun 2015 sebanyak 5151 orang. Dimana prevalensi tertinggi penderita DM di Kota Bangkinang yaitu sebanyak 503 orang $(9,76 \%)$.

Semakin meningkatnya kasus diabetes di Indonesia tentunya sangat memprihatinkan. Di sisi lain, penyakit diabetes merupakan penyakit preventif yang dapat dicegah melalui perubahan gaya hidup yang lebih sehat. Selain itu pada penderita DM Tipe II terjadi penurunan respon jaringan perifer terhadap insulin, peristiwa tersebut dinamakan resistensi insulin. Resistensi insulin mengakibatkan pengaturan glukosa yang tidak terkontrol sehingga terjadi peningkatan kadar glukosa darah atau hiperglikemia. Flavonoid yang terkandung di dalam kayu manis bekerja dengan meningkatkan metabolisme glukosa dan mengubah glukosa menjadi energi. Proses tersebut meningkatkan sensitivitas sel terhadap insulin sehingga kadar glukosa darah menurun. Tanaman kayu manis merupakan alah satu alternatif dalam penyembuhan penyakit DM, karena tanaman ini mengandung senyawa kimia seperti safrole, minyak atsiri eugenol, tenin, sinamaldehyde, damar, kalium oksalat dan penyamak, serta flavonoid (Hastuti, 2014).

Pada umumnya, penderita DM tipe II mengkonsumsi obat-obat kimia untuk menurunkan kadar gula darah. Obat kimia tersebut dapat memberikan efek yang negatif bagi tubuh. Karena obat-obat diabetes yang ada sekarang ini masih belum sepenuhnya memberikan solusi untuk para penderita diabetes. Selain harganya yang cukup mahal, banyak efek samping yang ditimbulkan pada pemakaian obat-obatan kimia tersebut. Hal inilah yang menyebabkan masyarakat mulai mencari alternatif pengobatan yang lain. Salah satunya adalah melalui terapi rebusan kayu manis (Cahyadu, 2013).

Berdasarkan hasil penelitian yang dilakukan oleh Hananti (2012), menyatakan bahwa ekstrak etanol kulit kayu manis dosis 50, 100, dan 200 $\mathrm{mg} / \mathrm{kg}$ bb mampu menurunan kadar glukosa darah pada mencit jantan yang diinduksi glukosa $2 \mathrm{~g} / \mathrm{kg}$ bb dengan metode uji toleransi glukosa. Penurunan kadar glukosa darah disebabkan oleh adanya senyawa flavonoid yang dapat meningkatkan sensitivitas sel $\beta$-pankreas untuk melepaskan insulin. 
Berdasarkan hasil survei awal yang dilakukan di Desa Kumantan Wilayah Kerja Puskesmas Bangkinang kota, dari 15 orang penderita Diabetes Mellitus tipe II,2 orang mengatakan pernah mencoba kayu manis sebagai obat herbal penurun kadar gula darah, 3 orang mengatakan bahwa mereka hanya mengetahui kayu manis sebagai bahan penyedap rasa makanan, sedangkan 10 orang lainnya mengatakan bahwa mereka belum mengetahui tentang kayu manis, cara mengkonsumsi serta manfaat dari kayu manis. Selama ini masyarakat penderita diabetes mellitus tipe II hanya mengkonsumsi obat - obat kimia untuk mengatasi kadar gula darah mereka yang tinggi tanpa memikirkan efek samping dari obat kimia tersebut.

Berdasarkan latar belakang yang telah diuraikan diatas, maka peneliti tertarik untuk meneliti tentang "Adakah efektivitas kayu manis terhadap penurunan kadar gula darah pada penderita DM tipe II di Desa Kumantan Wilayah Kerja Puskesmas Bangkinang Kota tahun 2016.

\section{Metode Penelitian}

Jenis penelitian ini menggunakan metode eksperimen semu (quasi exsperimen) dengan rancangan non-equivalentpretestposttest. Intervensi yang digunakan dalam penelitian ini adalah pemberian kayu manis $2 \mathrm{x}$ sehari pada pagi dan sore selama 7 hari. Metode nonequivalent pretest-posttestini digunakan untuk melihat pengaruh konsumsi rebusan kayu manis terhadap penurunan kadar gula darah penderita diabetes mellitus di Desa Kumantan wilayah kerja puskesmas Bangkinang kota. Perebusan kayu manis akan dilakukan di laboratorium Universitas Riau.

\section{Bahan dan Alat}

Bahan baku yang digunakan dalam pembuatan ekstrak kayu manis adalah kayu manis.

Alat yang digunakan dalam pembuatan ekstrak kayu manis adalah dandang, kompor yang akan digunakan untuk perebusan kayu manis

\section{Analisis Data}

Analisi data dimulai dari entri, coding, cleaning dan dianalisis menggunakan SPSS. Data dianalisis secara deskriptif dan inferensia. Data deskriptif berupa karakteristik responden meliputi umur, pekerjaan dan jenis kelamin. Sedangkan data inferensia berupa pengaruh intervensi pemberian ekstrak kayu manis terhadap penurunan kadar gula darah pada penderita DM Tipe II.

\section{Hasil Penelitian}

Penelitian ini dilakukan pada bulan April-Agustus tahun 2017 di Desa Kumantan Wilayah kerja Puskesmas Bangkinang Kota dengan 20 responden yang menderita DM Tipe II, Responden tersebut telah memenuhi kriteria inklusi dan telah mengonsumsi ekstrak kayu manis untuk menurunkan kadar gula darah pada penderita DM Tipe II. 
1. Rata-rata kadar gula darah responden sebelum dan sesudah intervensi

Kadar gula darah dapat dijadikan indikator untuk melihat apakah seseornag menderita DM Tipe II atau tidak. Banyak faktor yang menyebabkan kejadian DM Tipe II diantaranya adalah faktor keturunan, gaya hidup, pola konsumsi makan, aktifitas fisik, dan lain sebagainya. Faktor utama yang sering menyebabkan kejadian DM adalah pola konsumsi yaitu makanan manis dengan kandungan indeks glikemik (IG) yang tinggi yaitu salah satunya adalah makanan pokok yaitu nasi, dimana penduduk Indonesia mengonsumsi nasi 2-3 kali sehari dengan porsi yang berlebihan. Selain komsumsi makanan dengan IG tinggi faktor lain yang menyebabkan DM adalah gaya hidup yang salah yaitu rendanhya aktifitas fisik, tingginya angka perokok, dan faktor lainnya adalah faktor genetik atau keturunan..

Seseorang dikatakan menderita DM Tipe II jika memeiliki kadar glukosa darah >200 mgHg. Rata-rata kadar gula darah responden yang mengalami DM Tipe II sebelum dan sesudah diberikan intervensi berupa ekstrak kayu manis dapat dilihat pada tabel 4.2 sebagai berikut:

Tabel 4.2 Rata-rataKadar Gula Darah Sebelum Pemberian Rebusan Kayu Manis di Desa Kumantan wilayah Kerja Puskesmas Bangkinang Kota tahun 2016
Berdasarkan tabel 4.2 dapat dilihat ratarata kadar gula darah sebelum diberikan rebusan kayu manis responden adalah $263,40 \mathrm{mg} / \mathrm{dl}$ dengan standar deviasi 22,486 , sedangkan rata-rata kadar gula darah seteleh diberikan intervensi mengalami penurunan menjadi 225,65 dengan standar deviasi 22,413. Meskipun mengalami penurunan kadar gula darah setelah diberikan intervensi berupa ekstrak kayu manis, tetapi kadar gula darah masih tergolong tinggi, tetapi sudah mengalami penurunan dari sebelum diberikan ekstrak kayu manis.

Hal ini dikarenakan banyak faktor yang mempengaruhi diantaranya adalah pola konsumsi responden yang masih banyak mengonsumsi maknan manis dengan tinggi indek glikemik. Tingginya indek glikemik pada suatu bahan makanan akan mempercepat kenaikan kadar gula darah seseorang, selain itu tingginya kadar gula darah responden dipengaruhi oleh rendahnya aktivitas fisik responden, hal ini ditandai oleh banyak responden yang suka dudukduduk sambil bercerita ketika penelitian berlangsung,dan hal lainnya mungkin disebbkan lama waktu intervensi (Anwar 2011).

2. Pengaruh Intervensi Pemberian Ekstrak Kayu Manis Terhadap Penurunan Kadar Gula Darah Pada Responden DM Tipe II

Intervensi pemberian ekstrak kayu manis pada responden dilakukan selama 7 hari dengan pemberian 2 kali sehari yaitu pada pagi dan sore hari oleh peneliti. Pengaruh pemberian ekstrak kayu manis terhdap penurunan kadar gula darah responden dianalisis menggunakan uji regresian linier dapat dilihat pada tabel 4.3 sebagai berikut.

\begin{tabular}{lcccc}
\hline Variabel & Mean & CI 95\% & SD & Min-Max \\
\hline Sebelum & 263,40 & 252,88 & 22,486 & $204-292$ \\
\hline Sesudah & 225,65 & 215,16 & 22,413 & $175-256$ \\
\hline \multicolumn{5}{r}{ Sumber: Hasil Penelitian }
\end{tabular}

Sumber: Hasil Penelitian 


\begin{abstract}
Tabel 4.3Pengaruh ekstrak kayu manis terhadap penurunan kadar gula darah responden DM tipe II
\end{abstract}

methylhydroxychalcone polymer (MHCP). MHCP merupakan suatu polyphenol (flavonoid) MHCP mempunyai kerja seperti

\begin{tabular}{|c|c|c|c|c|c|}
\hline Variabel & B & $\begin{array}{c}\mathbf{R} \\
\text { Square }\end{array}$ & SD & SE & $\begin{array}{l}\text { herja } \\
\text { Sig } \\
\text { insulin,terhadap insulin sehingga kadar }\end{array}$ \\
\hline $\begin{array}{l}\text { Pemberian } \\
\text { ekstrak kayu }\end{array}$ & 0.546 & 0.450 & 22,486 & $\begin{array}{c}5,02 \\
8\end{array}$ & gbogkosa darah menurun. \\
\hline
\end{tabular}
manis

Sumber: Data uji analisis regresi linier

Pemberian ektrak kayu manis efektif dalam penurunan kadar gula darah pada penderita DM Tipe II. Semakin sering dan lama periode pemberian ekstrak kayu manis, maka semakin baik dalam penurunan kadar gula darah responden (Muliani, 2012).

Hasil penelitian uji regresi linier menunjukkan bahwa terdapat pengaruh sigifikan $(\mathrm{p}<0.05)$ pemberian ekstrak kayu manis terhadap penurunan kadar gula darah responden dan diketahui bahwa kedua variabel saling berpengaruh. Pengaruh tersebut disimbolkan dengan $\mathrm{R}$ square (Tabel 4.3). Berdasarkan Tabel 4.3 nilai $R$ square adalah 0.450 yang artinya bahwa ekstrak kayu manis memberikan kontribusi penurunan kadar gula darah sebesar 0.450 atau 45\%. Artinya sebanyak $45 \%$ penurunan kadar gula darah responden dipengaruhi oleh ekstrak kayu manis dan 55\% dipengaruhi oleh faktor lain yang tidak terangkum dalam penelitian. Asumsi peneliti 55\% mugkin dipengaruhi oleh gaya hidup (aktivitas fisik, kebiasaan merokok), pola konsumsi makan terutama makanan manis dengan IG tinggi dan faktor keturunan.

Menurut Anderson (2006) kayu Manis (Cinnamomum burmani) mengandung minyak atsiri, safrole, sinamaldehide, tannin, kalsium oksalat, dammar, dan zat penyamak. Antioksidan yang terkandung antara lain eugenol dan
Menurut Maria (2013) flavonoid yang terkandung dalam kayu manis dapat mempengaruhi fungsi glukosa dan insulin didalam tubuh. Polifenol akan merangsang autofosforisasi reseptor insulin melalui peningkatan aktivitas forforisasi tirosin dan menurunkan proses defosforisasi.

Menurut Ramzi (2012) kandungan flavonoid yang terkandung didalam kayu manis bekerja dengan meningkatkan metabolisme glukosa dan mengubah glukosa menjadi energi. Proses tersebut meningkatkan sensitivitas sel terhadap insulin sehingga kadar glukosa darah menurun. Pada ekstrak etanol Cinnamon terdapat komponen utama yang disebut dengan procyanidins yang memiliki aktivitas biologi mirip insulin.

Hasil penelitian ini juga sejalan dengan penelitian yang dilakukan oleh Ramadhona (2016) dengan judul pengaruh pemberian seduhan bubuk kayu manis terhadap penurunan kadar gula darah postprandial pada penderita DM Tipe II di wilayah kerja Puskesmas Pauh Kota Padang Tahun 2015. Berdasarkan uji Paired T-Test terdapat penurunan kadar gula darah penderita DM Tipe II sebelum dan sesudah pemberian seduhan bubuk kayu manis dengan nilai $\mathrm{p}$ 0,000. Hal ini menunjukkan bahwa pemberian seduhan bubuk kayu manis dapat menurunkan kadar gula darah penderita DM Tipe II. 


\section{DAFTAR PUSTAKA}

Arif, (2009), Penanganan penyakit diabetes melitus, Jakarta: Kanisius

Firman, (2010), Pengobatan Alternatif Bagi Diabetes, Fakultas Pendidikan Kesehatan dan Rekreasi, UI. Jakarta

Dinkes Provinsi Riau, (2013). Profil Kesehatan Provinsi Riau. Pekanbaru

Depkes RI, (2009), Prevalensi Penyakit Diabetes Mellitus, Dalam http://www.depkes.go.id/down load. publikasi ditjen (diakses padatanggal

12 Maret 2016)

Dewi, (2014), efektivitas ekstrak etanol kulit batang Kayu Manis terhadap penurunan kadar gula darah tikus putih jantan galur wistar, Dari http//pdf/kayumanis.adobe reader. Diperoleh pada tanggal 20 Maret 2016

Handra, (2014), Pengaruh pemberian ekstrak kayu manis (Cinnamomun Burmannii) terhadap penurunan kadar glukosa darah tikus wistar yang diberi beban glukosa, Diperoleh pada tanggal 10 Maret 2016

Hastuti, (2014), Diabetes: Panduan

Lengkap Untuk Diabetes, Jakarta: Mizan

Utama

Hidayat, A.A. (2011), Riset

Keperawatan dan Teknik
Penulisan Ilmiah, Jakarta :

Salemba Medika

Hiwal, (2007), Cara Ampuh Mengusir

Diabetes Melitus, Jakarta: Nuha

Medika Iyer, (2009),

Pengobatan tradisional diabetes melitus, Jakarta: Rineka Cipta

Kasjono \&

Yasril, (2009), Teknik Sampling

Untuk Penelitian Kesehatan,

Yogyakarta : Graha Ilmu

Manganti, (2014), Konsesus

Pengelolaan dan Pencegahan

Diabetes Mellitus

Tipe 2 di Indonesia, Jakarta:

Departemen Kesehatan

Mistra, (2012), Pengobatan Diabetes

Melalui Pola Makan, Kawan

Pustaka, Jakarta

Notoadmodjo, Dr.Soekidjo, (2010), Metodologi Penelitian

Kesehatan, Jakarta: Rineka Cipta

Zamzami, (2011), Masalah

Diabetes Mellitus di

Indonesi,.Jakarta: Balai

Penerbit FKUI

Susanti, (2015). Cara mengkonsumsi kayu manis. Dari http//carakonsumsi- kayu-manis. Diperoleh tanggal 18 April 2016

Tara, (2008). Patofisiologi Konsep Klinis Proses - Proses Penyakit. Jakarta: Buku Kedokteran EGC 